\title{
DNA Barcoding of Swamp Sediment Bacterial Isolates for Swamp Aquaculture Probiotic
}

\author{
Marini Wijayanti ${ }^{1 *}$,Dade Jubaedah ${ }^{1}$,Januar Ahlan Suhada ${ }^{1}$,Siti Yuliani ${ }^{1}$,Nabilah \\ Saraswati ${ }^{1}$, Tanbiyaskur ${ }^{1}$,Mochamad Syaifudin ${ }^{1}$, and Hary Widjajanti ${ }^{2}$ \\ ${ }^{1}$ Aquaculture Study Program, Department of Fisheries, Faculty of Agriculture, Universitas Sriwijaya, \\ Ogan Ilir, South Sumatera, Indonesia \\ ${ }^{2}$ Department of Biology, Faculty of Mathematics \& Natural Sciences, Universitas Sriwijaya, Ogan \\ Ilir, South Sumatera, Indonesia
}

\begin{abstract}
Bacteria derived from swamp sediments and aquaculture ponds potential to be probiotics. The study aims to determine the sequence of $16 \mathrm{~S}$ $\mathrm{r}$ RNA gene of isolate of probiotics candidate bacteria from sediment of swamp, to determine the phylogenetic tree between the bacterial species from isolates and Gene Bank data central for their potential as probiotic. The samples of bacteria resulted from pure isolation selected from the sediment of pond cultivation and swamp waters at Lebung Karangan Reservation, Ogan Ilir Regency, Indralaya, South Sumatra. This study was started from cultivating bacteria, extracting DNA of bacteria, amplification $16 \mathrm{~S}$ r RNA genes by PCR, running electrophoresis, and sequencing the amplicon for determining DNA barcodes of bacteria from sediment of swamp and rearing pond. The result of BLAST analysis showed that KA isolate had the highest similarity $97 \%$ with Streptomyces $s p$. Hjorring 101 from Denmark and RA isolate had the highest similarity $98 \%$ with Streptomyces $s p$. BD99 from Pakistan. KE isolate had the highest similarity $99 \%$ with Bacillus subtilis CESi5 from Japan and RE isolate had the highest similarity $93 \%$ with Bacillus sp.2bFR from Manado. All of isolates were bacteria potentially as swamp aquaculture probiotics.
\end{abstract}

\section{Introduction}

The swamp aquaculture had been developing at South Sumatra, Indonesia. Swamp land can be optimized based on its water level. The swamp land can be cultivated using rotation model of agriculture and aquaculture-fish farming (catfish, snake head fish, tilapia) in deep swamp land [1]. The aquaculture have unique characteristic of their system. The absorption pond make them depend on around water quality of environment. Swamp aquaculture have been one of problem solution for optimizing sub optimal low land system in order to increase welfare society by swamp fish production. The problems of swamp aquaculture are water quality and feed conversion ratio of swamp fish as like as Channa fish culture problems. The problem can be approached by specific swamp probiotic for increasing water quality and feed efficiency of swamp fish aquaculture.

Sediments contain abundant populations of microorganisms with high diversity [2]. Swamp sediments contain organic waste that settles at the bottom of the waters. Bacteria 
can grow in swamp sediments due to the presence of organic waste. Organic matter is an energy source for soil flora and fauna [3]. Bacteria from aquaculture ponds due to organic waste, some of which come from the excretion of aquatic organisms, food waste and carcasses of organisms that settle at the bottom of the pond. Bacteria derived from swamp sediments and aquaculture ponds can be used as probiotic candidates.

Probiotics are living microbial agents that are able to provide benefits to the host by improving nutritional value and utilization of feed, increasing host response to disease and improving environmental quality [4]. Probiotics will be more effective when using indigenous (native) microorganisms which obtained from the digestive tract and the environment that are the same or similar to host animals [5]. Streptomyces strains as well as their combination with Bacillus and the multistrain Bac-Strep are the most favorable probiotic candidates to be used in aquaculture because they exert a probiotic effect on shrimps by improving growth parameters, regulating immune response, modulating host and water microbiota, and increasing resistance to disease [6]. Streptomyces has potential as a candidate for probiotics and as well as an alternative to antibiotics in maintaining a sustainable aquaculture [7].

Common bacterial identification is carried out based on morphological, physiological, and biochemical observations [8]. Characterization of bacteria based on the appearance of morphology, physiology, and biochemical testing results are less stable, less uniform and strongly influenced by subjective judgments. This results in the number of strains of bacteria obtained are usually very small compared to the actual diversity of bacteria [9]. To ascertain the species of bacteria that are thought to be potential candidates for probiotics, there is a need for genetic identification that shows the results of specific identification. For this reason, it is necessary to know the molecular characteristics of probiotic bacteria using $16 \mathrm{~S}$ rRNA gene sequencing. The isolation of bacterial strains that have the potential as probiotics, followed by molecular testing using $16 \mathrm{~S}$ rRNA to ascertain the species.

DNA barcoding using 16S rRNA gene has been widely used in knowing the molecular DNA characterization of bacteria. The development of bacterial DNA barcoding with errorindependent and time-saving technique has increased dramatically, which helps in identifying the microbes and understanding the microbial biodiversity [10]. In the development of swamp fish culture identification of swamp bacteria using 16S rRNA gene needed to obtain the characterization of swamp bacteria that would later be expected to be potential bacteria as probiotics and determine the structure of phylogenetic trees that have been recorded in Gen Bank. The purpose of this study were to know the feasibility of bacterial isolates that have the potential as probiotics from swamp sediments and catfish culture ponds based on their proximity to the probiotic genus by phylogenetic tree approach.

\section{Materials and Methods}

The bacteria tested came from the location of the cultivation pond and common swamp sediments in the Reservoir Lebung Karangan, Ogan Ilir Regency, Indralaya, and South Sumatra. Four bacterial colonies tested were two eubacterial colonies and two actinomycetes colonies. Eubacteria colonies implanted in new petri dishes containing NA (Nutrient Agar) media by scraping 4 quadrants to get a single colony. Petri dishes were wrapped in wrapping paper and incubated for 2 days at room temperature $\left(28^{\circ} \mathrm{C}-30^{\circ} \mathrm{C}\right)$ and then observed until the bacteria grew [11]. Actinomycetes colonies implanted in a new petri dish containing the agar medium for YM (Yeast Malt Agar) by scraping 4 quadrants to get a single colony. The cultures were stored at $28-30^{\circ} \mathrm{C}$ for 5 days [12]. 
The bacterial DNA extraction process was carried out using PrestoTM Mini gDNA Bacteria Kit (Geneaid Biotech Ltd.). The sample required $1 \times 10^{9}$ bacterial cell for one extraction. DNA extraction procedures were carried out in accordance with the PrestoTM Mini DNA Bacteria Kit manual. PCR material was used by $25 \mu \mathrm{l}$ of DNA extraction. Each reaction contains: go taq green $12.5 \mu \mathrm{l}, 2$ pairs of primers $16 \mathrm{~S}$ rRNA namely primer $63 \mathrm{f} 1$ $\mu \mathrm{l}$, primer 1387r $1 \mu \mathrm{l}$, NFW (Nuclease Free Water) $6.5 \mu \mathrm{l}$, template DNA $4 \mu \mathrm{l}$. DNA amplification was carried out by stages: initiation cycle at $95^{\circ} \mathrm{C}$ for 5 minutes, denaturation at $94^{\circ} \mathrm{C}$ for 30 seconds, primary annealing or sticking at $50^{\circ} \mathrm{C}$ for 1 minute, extension or elongation at $72^{\circ} \mathrm{C}$ for 2 minutes in 30 cycles and the final extension at $72^{\circ} \mathrm{C}$ for 5 minutes [13]. PCR products were electrophoresed through $1 \%$ agarose electrophoresis gel. Loading dye as much as $1 \mu \mathrm{L}$ was mixed with $6 \mu \mathrm{L}$ of DNA inserted in each electrophoresis well. Electrophoresis was carried out with $75 \mathrm{~V}$ power for 50 minutes and the results were soaked into $1 \mathrm{X}$ TAE which had been added with diamond nucleic acid dye for 30 minutes, then visualized with Gel Doc. DNA size of Gel Doc results was defined by using marker $1 \mathrm{~kb}$. The amplicons that have been known for DNA size using electrophoresis, were sequenced through the Macrogen, Korea via PT Indolab, Jakarta.

The sequences that have been obtained in the form of fasta format are then aligned using MEGA 6.0 software, then the aligned sequence is taken and then BLAST (Basic Local Alignment Search Tool) is used to determine the homology of a DNA sequence or amino acid with the data contained in Genbank NCBI (National Center for Biotechnology Information) and Barcode of Life. Then all sequences were aligned to analyze genetic distance and phylogenetic trees. Phylogenetic trees between bacterial species were constructed using the Maximum Likelihood method.

\section{Results and Discussions}

The isolates of bacteria were 4 pure isolates consisting of 2 eubacteria isolates and 2 actinomycetes isolates, each bacteria derived from sediments of swamp waters and aquaculture ponds. The number of isolates used for cultivation and propagation of isolates is presented in Table 1.

Table 1. Bacterial isolates used in cultivation and multiplication of bacterial isolates

\begin{tabular}{|c|c|c|c|c|}
\hline No. & $\begin{array}{c}\text { Sample } \\
\text { Code }\end{array}$ & Isolates & Media & Origin of Sediment \\
\hline 1. & KA & Actinomycetes & YM (Yeast Malt Agar) & Swamp Fish Pond \\
\hline & RA & Actinomycetes & YM (Yeast Malt Agar) & Swamp water \\
\hline 2. & KE & Eubacteria & NA (Nutrient Agar) & Swamp Fish Pond \\
\hline & RE & Eubacteria & NA (Nutrient Agar) & Swamp water \\
\hline
\end{tabular}

Amplification of bacterial DNA using PCR method with 16S rRNA 63F universal primer and 1387R as well as $4 \mu \mathrm{L}$ template from DNA from eubacteria and actinomycetes extraction. DNA visualization is presented in Figure 1. Based on Figure 1 visualization of the results of 16S rRNA amplification on actinomycetes and eubacteria measuring $1342 \mathrm{bp}$. Marchesi et al. (1998) arranged primers 63F and 1387R to amplify the 16S rRNA gene from Domain bacteria. This primary pair is able to amplify the gene with a size of about 1300 base pairs. Bacterial amplification using $63 \mathrm{~F}$ and $1387 \mathrm{R}$ primers produced an average 16S rRNA gene fragment size of $\pm 1350 \mathrm{bp}$ [14]. 


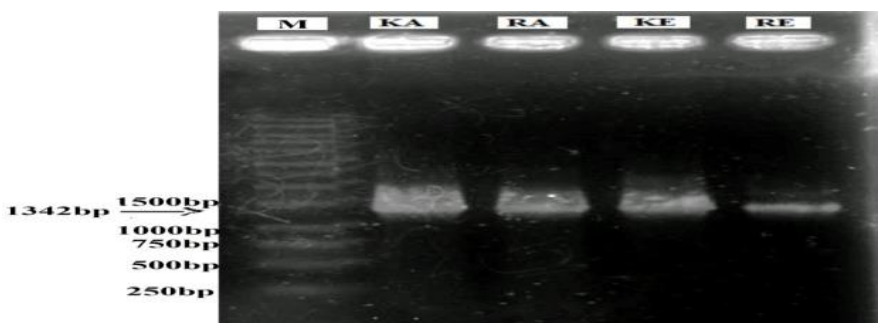

Fig. 1. Visualization of the results of bacterial 16S rRNA gene amplification $M=$ DNA Marker $1 \mathrm{~kb}$; $1=16 \mathrm{~s}$ rRNA gene of isolate KA; $2=16 \mathrm{~s}$ rRNA gene of isolate RA; $3=16 \mathrm{~s}$ rRNA gene of isolate $\mathrm{KE} ; 4=16 \mathrm{~s}$ rRNA gene of isolate RE

The visualization process is one of the ways to determine the quality of DNA isolates and ensure the suitability of the primers used by looking at the base pair length (bp) [15]. The success of PCR techniques is based more on primary suitability and efficiency and optimization of the PCR process. Non-specific primers can cause amplification of other areas in the genome that are not targeted or otherwise there is no amplified genome area. PCR optimization is also needed to produce the desired character. This optimization concerns the temperature of DNA annealing in PCR machines [16].

The sequencing results that have been obtained are then aligned using the Mega 6.0 software. After aligning it produces a sequence of nucleotide bases with a length of $1324 \mathrm{bp}$ (Isolate KA), 1328 bp (Isolate RA), 1324 bp (Isolate KE), and 1342 bp (Isolate RE). Furthermore, isolates were analyzed through BLASTn (Basic Local Alignment Search Tool-nucleotide) on the NCBI (National Center for Biotechnology Information) site showing the results of the percentage similarities in eubacteria and actinomycetes samples with the data contained in Genbank are presented in Table 2. Based on Table 2, the results of BLAST analysis of the 16S rRNA gene nucleotide sequences of actinomycetes samples from KA isolates had the highest identity percentage of $97 \%$ with Streptomyces sp. Hjorring101 from Denmark. Whereas actinomycetes from RA isolates had the highest percentage of identity $98 \%$ with Streptomyces sp. BD99 from Pakistan.

In eubacteria the isolate KE has the highest percentage of identity $99 \%$ with the Bacillus tequilensis JS5L species from China, Bacillus sp. BAB-6024 originating from India and Bacillus subsp species. CESi5 subtitles originating from Japan. Eubacteria isolate RE has the highest percentage of identity $93 \%$ with Bacillus albus AB-CSL3 species originating from India, Bacillus cereus PCt-1 species originating from Pakistan, Bacillus cereus PD3 species originating from India, Bacillus cereus BDU8 species originating from Indonesia, Bacillus sp.2bFR species originating from Manado, Indonesia, Bacillus sp. G6 species from Bogor, Indonesia and Bacillus thuringiensis 13 species from Sri Lanka. If homology has a percentage close to $100 \%$ or above $97 \%$ it can be confirmed as a related species but vice versa if the homology is smaller than $97 \%$ the possibility of isolates is a new species or species cannot be confirmed [17].

Table 2. Results of BLASTn analysis of eubacteria and actinomycetes samples with data in Genbank

\begin{tabular}{|c|c|c|c|}
\hline Bacterial Species & $\begin{array}{c}\text { Identity } \\
\mathbf{( \% )}\end{array}$ & $\begin{array}{c}\text { Accesion } \\
\text { number }\end{array}$ & Origin of Samples \\
\hline Actinomycetes (Isolate KA) & & & \\
\hline Streptomyces sp. Hjorring101 & 97 & EU010382.1 & Denmark \\
\hline Streptomyces coelicolor A-JW-07 & 93 & MF083724.1 & India \\
\hline
\end{tabular}




\begin{tabular}{|c|c|c|c|}
\hline Streptomyces clavuligerus MTCC 7037 & 93 & EU146061.1 & India \\
\hline Streptomyces clavuligerus A-ZN-05 & 93 & MF083720.1 & India \\
\hline \multicolumn{4}{|l|}{ Actinomycetes (Isolate RA) } \\
\hline Streptomyces sp. BD99 & 98 & MF767903.1 & Pakistan \\
\hline Streptomyces sp. ess amH1 & 88 & KF996505.1 & Saudi Arabia \\
\hline Streptomyces sp.mixed culture J3-44 & 88 & KR029211.1 & China \\
\hline Streptomyces $s p . \mathrm{R} 11$ & 88 & KY631542.1 & India \\
\hline \multicolumn{4}{|l|}{ Eubacteria (Isolate KE) } \\
\hline Bacillus subtilis B15 & 99 & KJ870195.1 & India \\
\hline Bacillus tequilensis JS5L & 99 & KX129852.1 & China \\
\hline Bacillus sp. BAB-6024 & 99 & KY672884.1 & India \\
\hline Bacillus subsp. Subtilis CESi5 & 99 & KY886250.1 & Japan \\
\hline \multicolumn{4}{|l|}{ Eubacteria (Isolate RE) } \\
\hline Bacillus albus AB-CSL3 & 93 & MG780242.1 & India \\
\hline Bacillus cereus PCt-1 & 93 & KJ865573.1 & Pakistan \\
\hline Bacillus cereus PD3 & 93 & KX343942.1 & India \\
\hline Bacillus cereus BDU8 & 93 & KR351303.1 & Indonesia \\
\hline Bacillus sp.2bFR & 93 & KY038329.1 & Manado,Indonesia \\
\hline Bacillus sp.GG6 & 93 & LC055680.1 & Bogor,Indonesia \\
\hline Bacillus thuringiensis 13 & 93 & MG738335.1 & Sri Lanka \\
\hline
\end{tabular}

Phylogenetic trees were constructed through the Mega 6.0 software application using the Neighbor-Joining (NJ) method [18] Maximum Composite Likelihood and Substitutions models to include d: Transitions + Transversions with 1000x boostrap [19]. Eubacteria and actinomycetes phylogenetic trees are presented in Figure 2 and Figure 3. Two phylogenetic tree constructs were formed from 4 sequences obtained from the results of the study with 2 isolates namely actinomycetes KA and RA isolates, whereas eubacteria with isolates KE and RE isolates. Added 8 sequences for actinomycetes and 11 sequences for eubacteria derived from Genbank with accession numbers presented in Table 2.

The results of phylogenetic tree construction showed that the two samples formed different branches, the actinomycetes tree with a 0.01 scale and the eubacteria tree with a scale of 0.005 . Actinomycetes phylogenetic trees showed that samples of KA and RA isolates had a bootstrap value of $99 \%$ with Streptomyces sp. BD99 from Pakistan. It showed in the species forming its own sub cluster. Eubacterial phylogenetic trees showed that samples of KE isolates were in one sub cluster with Bacillus subsp species CESi5 subtilis from Japan which have been supported with 14\% bootstrap value. Meanwhile, eubacteria samples of RE isolates were in the sub cluster with Bacillus sp. 2bFR from Manado Indonesia which have been supported with $92 \%$ bootstrap value. Eubacterial phylogenetic trees showed that eubacteria samples from ponds isolate KE and eubacteria from swamp isolates RE formed different branches. The isolates KE and RE had different bacterial characteristics. The pond fish is more dominated by protein sources which comes from the remaining food, feces and some organic material carried during water intake. The swamps are dominated by cellulose sources. The remaining dead plants could be a source of cellulose in swamps, therefore the swamp is more dominated by cellulolytic bacteria. 


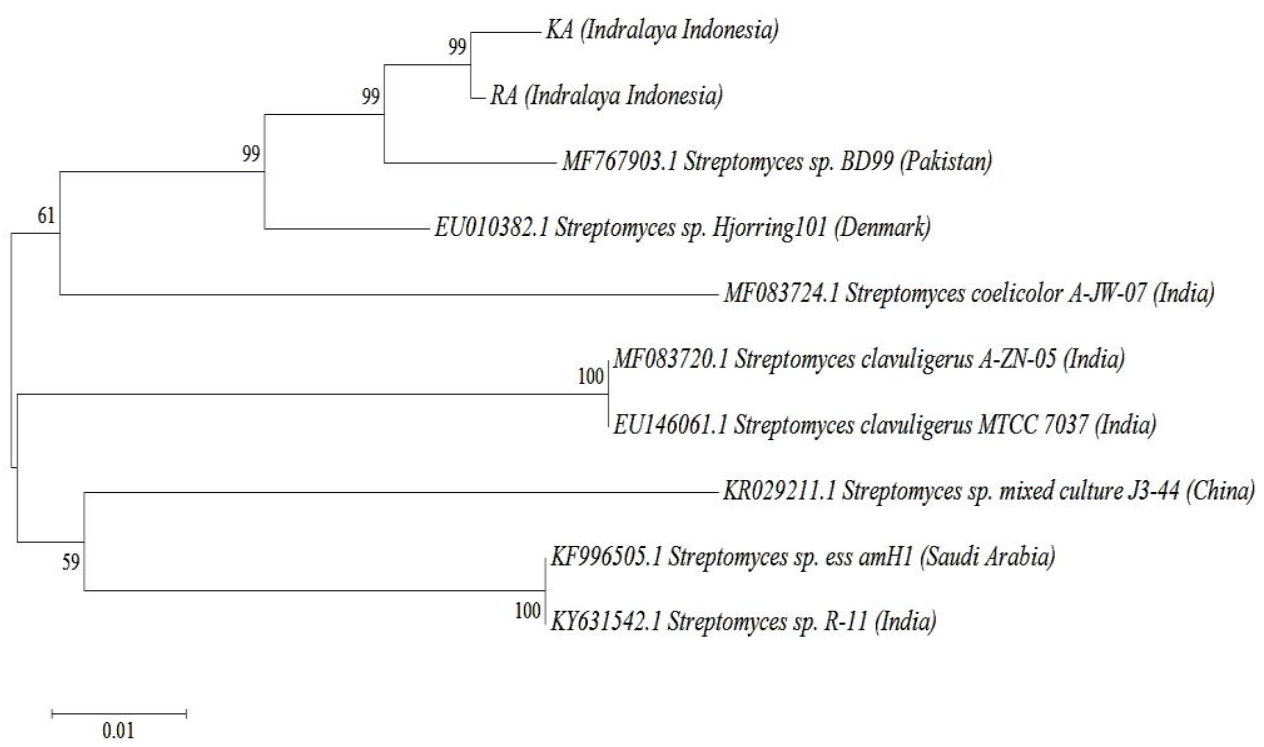

Fig. 2. The phylogenetic tree of actinomycetes isolates

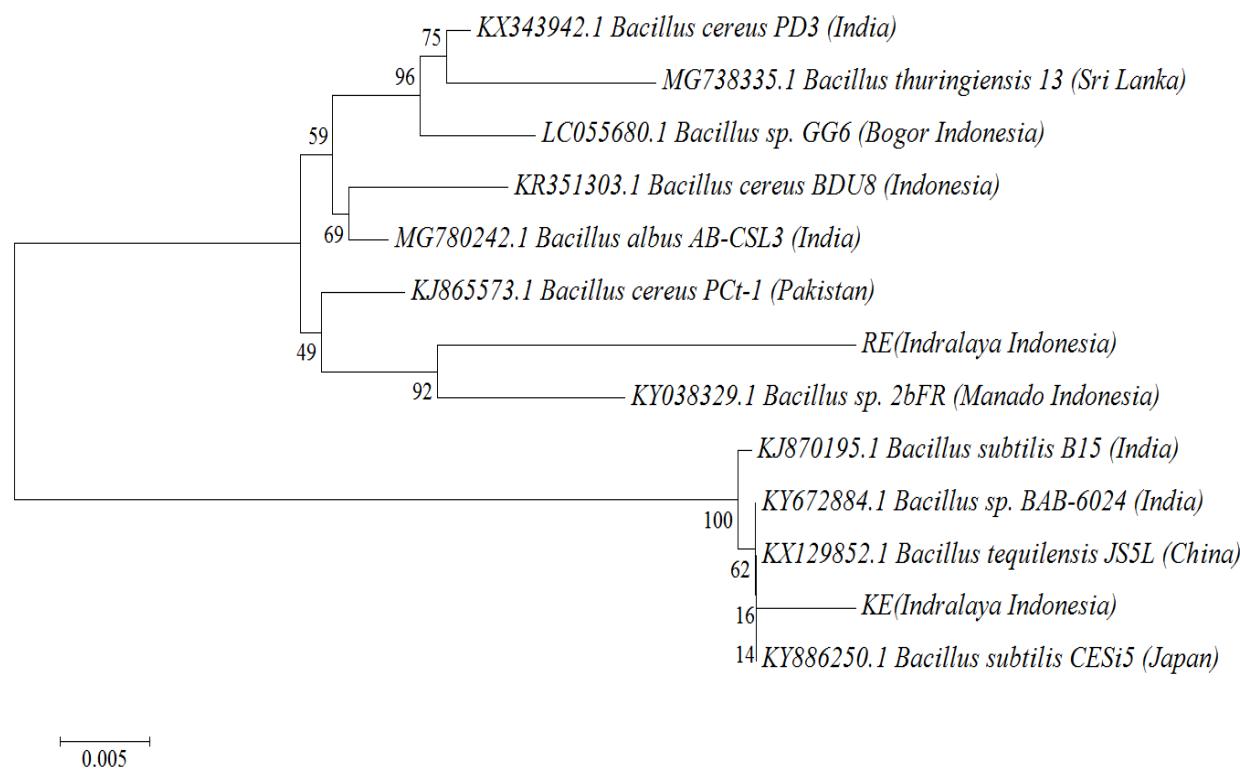

Fig. 3. The phylogenetic tree of eubacteria isolates

Bacillus is one type of bacteria that is widely used as a probiotic in aquaculture because of its ability to produce enzymes and antimicrobial components that can inhibit pathogenic bacteria [20]. Bacillus species are very suitable for use because they do not produce toxins, are easy to grow, do not require expensive substrates, Bacillus has the ability to withstand high temperatures, and the absence of metabolic byproducts [21]. Administration of Bacillus sp. with the right concentration and dose can increase the number of red blood cells and blood hemoglobin levels, this is believed to be one indicator of increasing the 
ability of fish in supplying nutrients to the entire body and tissue repair, so as to increase the growth of fish [22]. In addition, an increase in growth is also thought to be due to a decrease in the stress level of fish on water quality factors. So that the energy from the feed that enters the body of the fish is largely directed to growth. The probiotic Bacillus ND2 has the ability to stimulate better fish growth and accelerate the process of digestion of food into energy. The Bacillus ND2 could be anti-bacterial, also have the ability as quorum quenching which can block the signal of $A$. hydrophila when it reaches the quorum. In addition, Bacillus ND2 has the ability as an immunostimulant and can increase feed digestibility because it has lipolytic, proteolytic and amylolytic enzymes [23]. Bacillus bacteria can improve water quality, one of which reduces the content of ammonia $\left(\mathrm{NH}_{3}\right)$ and Nitrite $\left(\mathrm{NO}_{2}\right)$ [24]

Streptomyces is a genus of Actinomycetes class that has been proven to produce various antibiotics. More than 90 percent of the antibiotics produced from Streptomyces are used for the treatment of infectious diseases caused by bacteria [25]. This genera are known as a producer of various biologically active compounds, such as antibacterial, antifungal, antitumor, anticancer, antiparasitic, antiviral, immunomodulators, probiotic application in rearing water for sustainable aquaculture [7, 26, 27]. The administration of commercial probiotics containing Streptomyces sp. in feed increases the growth of red tilapia (Oreochromis sp.) [28]. Some Streptomyces strains alone or combined with other genera, primarily Bacillus, exert a probiotic effect on shrimps by improving growth parameters, regulating immune response, modulating host and water microbiota, and increasing resistance to disease [3]. Both of genera Streptomyces and Bacillus from swamp sediment could be probiotic for developing swamp aquaculture-swamp fish culture.

\section{Conclusions}

The conclusion of this study showed that isolates KA and RA from Indralaya have an identity percentage of $98 \%$ with Streptomyces sp. BD99 from Pakistan. KE isolate from Indralaya have an identity percentage of $99 \%$ with Bacillus subsp. CESi5 subtilis from Japan and RE isolate had an identity percentage of 93\% with Bacillus sp.2bFR from Manado. They could be potential candidates of swamp aquaculture probiotic.

\section{Acknowledgments}

This research was supported by the Sriwijaya University for an Unggulan Kompetitif research program in 2016-2018. The results will be dedicated for developing swamp aquaculture in Aquaculture Program, Department of Fisheries, Faculty of Agriculture, Sriwijaya University, South Sumatra, Indonesia.

\section{References}

1. H. Djusman. Opportunities to make a change (FORESPI, College Laguna Philippines, 2016)

2. A. Bisset, C. Burke,P.L.M. Cook, J.P. Bowman.Environmental Microbiology 9, 1 (2007)

3. R.R. Kusuma, L.Q. Aini, L. Khoirunnisaa, (Seminar Nasional Pembangunan Pertanian 2016) 
4. L. Verschuere, G. Rombaut, P. Sorgeloos, W. Verstraete. Microb. Mol. Bio. Reviews, 64, 4 (2000)

5. C. Yulvizar, I. Dewiyanti, C.N. Defira, Jurnal Teknologi dan Industri Pertanian Indonesia 6, 2 (2014)

6. M. G. Bernal, R. M. Marrero, Á. I. Campa-Córdova, J. M. Mazón-Suástegui. Aquacult Int 25, 2 (2017)

7. S. Hariharan, S. Dharmaraj. Therapeutic, Probiotic, and Unconventional Foods (Elsevier, 2018).

8. A. Wulandari,S.P. Prayitno, Sarjito. J. Aquaculture Management and Tech 3, 2 (2014)

9. Sarjito. Curr. Res. J. Bacteriol, 2,1 (2009).

10. M. Zubair, F. Fatima, S. Begum, Z.H. Siddiqui, In: S. Trivedi, H. Rehman, S. Saggu, C. Panneerselvam, S. Ghosh (eds) DNA Barcoding and Molecular Phylogeny. (Springer, Cham, 2018).

11. W.A. Setyati, Subagiyo. Jurnal Ilmu Kelautan 17, 3 (2012).

12. S. Kurniawati, K.H. Mutaqin, dan Giyanto. J. HPT Tropika 15, 2 (2015)

13. Nurhayati, B.S.L. Jenie, H.D. Kusumaningrum, S. Widowati, JID 12,2 (2011)

14. Faturrahman, J. Biol. Tropi 6, 2 (2005)

15. I. Riyantini, M.Yuniar, M.U.K. Agung, Jurnal Akuatik 5,1 (2014)

16. M. Aris, Sukenda, E.Harris, M.F. Sukadi, M. Yuhana, JBP 1, 3 (2013)

17. J.M. Janda, S.L. Abbott, Journal Of Clinical Microbiology, 45, 9 (2007)

18. N. Saitou, M. Nei, Molecular Biology and Evolution 4 (1987)

19. J. Felsenstein, J. Evolution, 39,783 (1985)

20. H.A. Hong, L.H. Duc, S.M. Cutting, FEMS Microbiology Reviews 29, 813 (2005)

21. E. Susanti, Biodiversitas 4,1 (2003)

22. M. Rajikkannu, N. Natarajan, P. Santhanam, B. Deivasigamani, J. Ilamathi, S. Janani, IJFAS 2, 5 (2015)

23. A.M. Lusiastuti, M.F. Ulkhaq, Widanarni, T.H. Prihadi, Jurnal Riset Akuakultur 11,2 (2016).

24. K.H. Linggarjati, A. Djunaedi, Subagiyo, Journal of Marine Research 2,1(2013).

25. T. Rahayu, Prosiding Seminar Nasional Biologi 8,1 (2011)

26. S.P. Salamoni, M.B. Mann, F.S. Campos, A.C. Franco, J.C. Germani, S.T.V.D. Sand, World J Microbiol Biotechnol 26, 1847 (2010)

27. M.A.O. Dawood, S. Koshio, M.M. Abdel-Daim, H.V. Doan, Reviews in Aquaculture 12, 1 (2018)

28. N. A'isah, T.Y. Mardiana, PENA Akuatika 13,1 (2016) 